\title{
Colorectal Cancer pN1b TNM Finding v8
}

National Cancer Institute

\section{Source}

National Cancer Institute. Colorectal Cancer pN1b TNM Finding v8. NCI Thesaurus. Code C134173.

Colorectal cancer in which two or three regional lymph nodes are positive. (from AJCC 8th Ed.) 